\title{
COVID-19: A Viral Phenomenon - Organizer \& Speaker Interviews
}

By: Martin Profant

\section{LMPSU EXECUTIVES: KAREN MAO AND ZIQI LIU}

\section{MARTIN: WHAT IS THE LMPSU?}

KAREN: The LMPSU is the representing body for LMP students providing academic supports, social events, and mentorship program. The LMPSU conference is an annual event and the one we take the most pride in!

\section{MARTIN: WHY DID YOU DECIDE TO HOST THIS YEAR'S CONFERENCE ON COVID-19?}

ZIQI: We thought it was a timely topic and a great opportunity to shed light on some of the research in the field of COVID-19.

MARTIN: WHAT WAS THE PROCESS LIKE TO ORGANIZE AND INVITE THE SPEAKERS?

ZIQI: We began organizing the conference in August. We made a list of potential speakers, ranked them in order of interest and emailed them. The keynote speakers were contacted first and helped to market the event to the other speakers.

KAREN: Dr. Lee gave us lots of useful advice; he said that speakers must represent the topic and that the quality of the conference is dependent on the speakers!

KAREN: Joe Bellisimo came up with the name "COVID-19: A viral phenomena". Then Britney Feng designed a poster, which represented Earth overlapped with coronavirus.

ZIQI: We did lots of marketing of the event through Facebook and social media, as well as emailed departments and course coordinators to inform their students of the event.

MARTIN: WHAT WERE THE PARTICULAR CHALLENGES RELATED TO ORGANIZING THIS YEAR'S EDITION OF THE LMPSU CONFERENCE?

ZIQI: Finding a suitable online platform was a challenge as most were too costly or too difficult to use. We decided to use Zoom webinar and also had a separate Zoom meeting to brief the speakers and test audio. Marketing was also challenge since everything is online, so it was difficult to spread the word.

KAREN: Some advantages were that the speakers could be located far away, like Dr. Joyner at the Mayo Clinic.

MARTIN: AFTER HEARING THE SPEAKERS'TALKS, WHAT ARE SOME THEMES THAT PARTICULARLY RESONATED WITH YOU?

KAREN: Dr. Joyner and Dr. Callum cross referenced each other often, which goes to show the tight knit community in science. Also, how COVID-19 is being fought on a national and international level. One thing that stuck me was Dr. Edwards quote: "A kilo prevention is better than a megaton of treatment."

MARTIN: AS STUDENTS YOURSELVES, WHAT WAS THE BIGGEST CHALLENGE YOU HAVE FACED THROUGHOUT THE COVID-19 PANDEMIC? ZIQI: I would say missing social interaction, friends, and face to face connection. Also, that the costs of amenities are still being charged by the university. There are also strict schedules on student research in the lab.

KAREN: I am missing the collaboration and vibrant environment in the lab. It has also influenced life science students particularly in second year, who have had a difficult time finding research positions or volunteering.

MARTIN: HOW DO YOU THINK STUDENTS CAN HELP COMBAT THIS PANDEMIC AND FUTURE ONES? HOW DID THIS CONFERENCE HELP WITH THAT?

ZIQI: Students have a responsibility to be educated and limit their in-person social interaction. The conference inspired students research preventative measures of pandemics. 
KAREN: Today's students will be the leaders that further the efforts of today's researchers. The speakers agreed to come talk to undergrads in order to inspire them to get involved in this type of research!

\section{SPEAKER: DR. ELEANOR FISH}

\begin{abstract}
MARTIN: WHAT INTERESTED YOU IN PRESENTING AT THE LMPSU CONFERENCE?

DR. FISH: I've been involved in doing some clinical trial activities internationally related to COVID. It was a convergence of my invitation to participate, plus our results, and it was an opportunity to share.
\end{abstract}

\section{MARTIN: I THANK YOU FOR COMING, YOUR TALK WAS EXCELLENT! HOW DID YOU GET INVOLVED IN COVID-19 RESEARCH?}

DR. FISH: I've been involved in looking at how viruses and the host us interact for many, many years. Viruses mutate so rapidly that if you target the pathogen, you're going to develop a medication that eventually the virus will develop resistance to, so my strategy has always been to understand how the host deals with infection. As a consequence of that many, many years ago, I started looking at some biologics called type one interferons: interferon alpha and interferon beta. They are our very first line of defense against any and all acute viral infections.

\section{MARTIN: OKAY, TELL ME A LITTLE BIT ABOUT HOW YOU STUDIED INTERFERONS IN RELATION TO COVID-19.}

DR. FISH: We have this nonspecific surveillance system in our bodies that detects virus, and the very first thing happens is that it will detect the genetic material of the virus and induce an interferon response. Every cell in our body can potentially be infected by a virus and has the capacity to produce interferon and to respond to interferon. I've worked with many different global virus outbreaks, perhaps the most notable would be SARS in 2000 to 2003, where we showed that interferons are very effective at clearing the virus in tissue culture and animal experiments.

When SARS-CoV-2 popped up in Wuhan, we asked the same question. Viruses co-evolve to encode in their genomes factors that will block interferon response; that's what happened with SARS, and what happens with Ebola and the flu. Not surprisingly, it's exactly the same with SARS-CoV-2, which is extremely efficient. So why was I interested is because there was more and more emerging evidence that the interferon response was blunted during a COVID-19 infection, so why not come in and treat with interferon? That's exactly what we did in an exploratory study in Wuhan at the start of the pandemic!
MARTIN: IS IT A MATTER OF JUST ADDING EXOGENOUS INTERFERON TO OVERRIDE THIS INHIBITION?

DR. FISH: There are a number of factors encoded in SARS-CoV-2 which block interferon production or signaling. It's a balancing act; the notion is if you come in early enough, yeah. Sufficient interferon on your override that block.

\section{MARTIN: I SEE. WHAT ARE THE CONCLUSIONS THAT YOU COULD DRAW FROM YOUR EXPLORATORY STUDY?}

DR. FISH: Interferons are most effective as antivirals. In other words, at inhibiting virus replication. Therefore, you want to treat early. By the time people are already in the intensive care unit, they've moved from the viral phase of disease into a severe inflammatory phase where interferon will no longer have any utility. So, what we attempted to do was treat only those individuals relatively early on in their disease, and our first observation was that we could clear the virus on average seven days faster than the standard of care at the time.

The second observation was that if we looked at circulating biomarkers of inflammation (IL-6, C reactive protein) we saw that those patients that received interferon had significantly reduced levels of both.

Finally, because this is a respiratory disease, all the action is initially in the lungs. We saw that patients that received interferon exhibited much less lung abnormalities and they resolved their disease from those lung abnormalities much faster.

MARTIN: YES, AFTER READING YOUR PAPER, I FOUND THE RESULTS QUITE DRAMATIC! SO, I GUESS THAT LEADS ME TO MY NEXT QUESTION; WHY IS THIS NOT WIDELY ADOPTED IN PRACTICE? DR. FISH: It's important to point out that this was an early exploratory study, not a randomized controlled trial. We really just wanted to explore whether interferon was going to have any utility. However, as a consequence of the results from that study, there are approximately 50 ongoing clinical trials trying to assess the effectiveness of interferon. In fact, my colleague, Tom Wilkinson, University of Southampton, and the company, Synairgen are running a phase three clinical trial where they're using an inhaled interferon. I'm running another trial with colleagues in Santiago in Chile, where we're not treating patients like the Synairgen trial, in hospital which might be too late but rather treating individuals who are still in their homes within three days of a positive test eligible people in the household.

MARTIN: FASCINATING, AS INTERFERON IS NOT NEW; IT'S BEEN AROUND FOR 25 YEARS, RIGHT? 
DR. FISH: Even longer. Older ones were first used for chronic hepatitis C. Later it was used in a number of viruses, cancers, and multiple sclerosis, but its primary mechanism of action is as an antiviral during an acute virus infection.

MARTIN: ONE MIGHT THINK THAT A PRO INFLAMMATORY CYTOKINE SUCH AS AN INTERFERON WOULD BE LIKE POURING GASOLINE ON A FIRE IN LIKE COVID-19, WHICH IS CHARACTERIZED BY LIKE EXCESSIVE INFLAMMATION. HOW IS IT THAT INTERFERON DOES NOT PRODUCE THESE EFFECTS? IN FACT, IN YOUR STUDY, YOU FOUND ACTUALLY DECREASED IL-6, WHICH IS A HALLMARK OF INFLAMMATION, RIGHT?

DR. FISH: It's all about timing. The primary mechanism action of interferon is to clear virus. When we say "proinflammatory", we are really referring to interferon's ability to elicit certain chemokines and cytokines that will attract various immune cells to clear the virus. The notion that later on if you give interferon, it will be pro inflammatory is probably not incorrect as the those activated cytokines will become involved in perpetuating the inflammatory response. This is why interferon should only be used early in disease.

MARTIN: NOW, I RECALL THAT ONE OF OUR OTHER SPEAKERS, DR. KOZAK, MENTIONED THAT HE WAS INVOLVED IN A SMALL TRIAL WITH INTERFERON LAMBDA, A TYPE THREE INTERFERON. I WAS WONDERING, HOW DO TYPE 3 INTERFERONS COMPARE WITH THE TYPE ONE INTERFERONS?

DR. FISH: The opportunity with interferons alpha and beta is that every cell type has a receptor for it, whereas interferon lambdas have a more restricted receptor expression. Another difference is that we have decades of experience with interferons alpha and beta, whereas we are just beginning to have experience with interferon lambda, and there are very few companies producing it.

\section{MARTIN: WHERE IS YOUR RESEARCH PROGRESSING WITH THE VACCINE?}

DR. FISH: The reality is that COVID-19 has a huge footprint around the globe. There will be a need for cost effective and widely-available therapies at least for the next couple of years. I feel that interferons may come into their own with this disease. And as I mentioned previously, they are effective against any and all viruses. Although we will all breathe a sigh of relief when COVID-19 is no longer a pandemic, the likelihood of a flu pandemic, the likelihood of another global virus outbreak, still exists. And I think it behooves us worldwide to develop broad spectrum antivirals and get ourselves prepared to use them at the start of an outbreak.
MARTIN: THROUGHOUT THE CONFERENCE, WE'VE SEEN THAT SCIENCE COLLABORATION IS CRUCIAL. HOW HAS YOUR RESEARCH BENEFITED IN THIS WAY, AND HOW HAS THE PANDEMIC CHANGED THE WAY SCIENCE IS BEING DONE?

DR. FISH: Collaboration is absolutely essential to move science forward quickly. No single lab has all the expertise to do everything. It is essential to build a network of collaborators, who become your friends, who share ideas with you, share research, and then you can move research forward quickly. You cannot work in solo! My collaborators are all around the globe!

MARTIN: I THINK SCIENCE'S ABILITY TO TRANSCEND BORDERS AND IDEOLOGIES IS REALLY INSPIRING. OTHER AREAS OF SOCIETY SHOULD TAKE NOTE! ESPECIALLY DUE TO COVID, ALL OF THE OPEN SOURCE MATERIAL IS AMAZING, AND I THINK IT'S REALLY CHANGED THE WAY SCIENCE BEING DONE.

DR. FISH: Cognisant of that, as somebody who's been doing research for many, many years, a number of years ago, I co-founded an organization called Beyond Sciences, young sciences initiative. This is an international network of young scientific scholars around the globe in over 70 countries around the globe. It's an opportunity for young scholars in Rwanda, Burkina Faso, Melbourne, Toronto, Brazil, and more to connect, share their science through a virtual platform and to hopefully develop relationships that will lead to collaborations and long-term professional relationships!

MARTIN: THAT'S INCREDIBLE. I'M GOING TO DEFINITELY LOOK INTO THAT ORGANIZATION. AND I HOPE MY READERS WILLAS WELL. LASTLY, WHILE WE ARE ON THE THEME OF YOUNG SCIENTISTS: WHAT DO YOU WANT BUDDING SCIENTISTS TO TAKE AWAY FROM YOUR TALK AND YOUR ORGANIZATION?

DR. FISH: It's a not for profit organization. We connect people together, and we run a free conference every year - this is the sixth one coming up in February. What l've learned is that connecting with like-minded people - people willing to take risks - and if you show integrity, and certainly in the health sciences, compassion, and an awareness that not everyone is as privileged as us and have the resources we do, you can build capacity around the globe. At the end of the day, it's science that's going to get us out of every single health crisis!

MARTIN: I COULDN'T AGREE MORE! IT'S BEEN AN ABSOLUTE PLEASURE TO SPEAK WITH YOU. THANK YOU, DR. FISH. 


\section{SPEAKER: DR. ROBERT KOZAK}

\section{MARTIN: FIRST OFF, WHAT INTERESTED YOU IN PRESENTING YOUR WORK AT THE LMPSU CONFERENCE?}

DR. KOZAK: I always think it's good to get to get information out there, there's nothing worse than doing science in isolation because when you share your ideas, not only do you get great questions but it's good as a way to put information out there for other researchers who may want to collaborate. I also try to make myself available to students, many of whom want to go into research, and you've got to give people the opportunities and help them get to the next step in the same way others have helped me.

\section{MARTIN: EXCELLENT. PLEASE TAKE US THROUGH YOUR WORK RECENT WORK ON COVID-19. \\ DR. KOZAK: I'm in a clinical microbiology lab, so we are at the frontlines of diagnostics and are interacting with many healthcare providers. As a result, a lot of my work has a very translational and clinical focus to it. There are three broad areas that that I'm involved with. Firstly, I'm doing a lot of work on diagnostics - everything from looking at different sample types to validating different assays. I'm happy to be working with Dr. Mubareka - she's a whole genome sequencing expert.}

The other two areas are therapeutics, which l've touched on regarding interferon lambda, a project I am working on with Dr. Jordan Feld. I'm also doing some screening assays looking at approved Health Canada compounds against coronaviruses. Even though we have a vaccine, and that's really great news, there are still people who are going to get sick, so we have to keep looking for new therapies. I am working with a collaborator of mine at Université Laval to do some monoclonal antibody testing.

But my true passion is vaccines, so again we're doing some work with collaborators at Université Laval investigating a DNA vaccine that we we've been testing in animal models. We are hoping that it'll move forward into clinical trials one day. Although we already have vaccines, we need more, and we may need ones that provide longer immunity.

\section{MARTIN: THAT'S INCREDIBLE WORK. IT SEEMS LIKE YOU'RE REALLY BUSY!}

DR. KOZAK: It's great to be involved in. Being in the in the clinical microbiology lab, the work you're doing may only be one or two steps removed from the patient and thus may potentially have an impact. That's what keeps me going.

MARTIN: PRECISELY. SO, YOU MENTIONED
DIAGNOSTICS, AND THERE'S KIND OF A

DEBATE NOW ABOUT WHETHER WE SHOULD KEEP THE GOLD STANDARD OF PCR, OR MOVE TO SOMETHING MORE RAPID? IS THERE AN ARGUMENT TO BE MADE FOR A CHEAPER BUT LESS SENSITIVE TEST?

DR. KOZAK: People have to understand the characteristics of the assay: the ratio of sensitivity to specificity, the limit of detection, and clinicians still have to use clinical judgment when doing testing. In my opinion, depending on the situation, there is use for rapid point of care testing, as well as for more sensitive tests.

For example, in some remote communities, if you're collecting a sample and then you have to fly it down to the south part of the province, there's a turnaround time of three to four days. So point of care testing may be more efficient. If you're positive, I know you're positive, but if you're negative, I still say, okay, we're going to do a more sensitive test, just to be doubly sure. It's about using the test the test correctly and appropriately.

MARTIN: A LOT OF PEOPLE SEEM TO BE WORRIED ABOUT THE RISK OF FALSE NEGATIVES. HOW BIG OF AN ISSUE DO YOU THINK THAT WOULD BE IF WE WERE TO SCALE UP TESTING?

DR. KOZAK: False negatives are of concern with any test, and because of the public health implications we are especially concerned with COVID-19. In such cases it is important not only to consider the properties of the test, but at other factors such as prevalence in your area. We need to use all these tools and our judgment together.

\section{MARTIN: INTERESTING. SO IT'S DEFINITELY MORE COMPLICATED THAN A LOT OF PEOPLE WOULD HAVE YOU BELIEVE?}

DR. KOZAK: Yes, what you need is lots of tools, lots of resources, and to give them to the right people the experts who will use and interpret them correctly. This often involves a whole team of people contributing expertise.

MARTIN: DEFINITELY. NOW, MOVING FROM TESTING TO TREATMENT, YOU MENTIONED YOUR INVOLVEMENT WITH INTERFERON LAMBDA. ONE OF THE OTHER SPEAKERS, DR. FISHE, MENTIONED TYPE ONE INTERFERONS. HOW DO THESE COMPARE IN THE TREATMENT OF COVID-19?

DR. KOZAK: To truly know that you would have to do a proper head-to-head clinical trial. Dr. Jordan Feld, a hepatologist, is the leader on this randomized controlled trial. He knows quite a lot about using interferon as interferons are sometimes used in the treatment of Hepatitis B. Interferon-lambda was being examined for the treatment of Hepatitis $D$, which is a virus that co-infects with Hepatitis $B$. One of the things that's very exciting about this interferon work is that 
you're not targeting the virus but rather activating the host immune response.

In our randomized controlled trial, we saw decline in viral load in some of the patients, but I haven't yet seen a randomized controlled trial for interferon alpha yet. Therefore, I'm not sure what the what the relative efficacy is. Most importantly, you have to pick the right patient group - for example, whether you're looking to decrease viral load, hospital discharge time, or the severity of symptoms, you would use different drugs. If you're aiming to do a comparison of two drugs, you have to ensure you have the same endpoint.

MARTIN: OKAY, I SEE. ANOTHER AREA UNDER INVESTIGATION IS MONOCLONAL ANTIBODIES. YOU MENTIONED YOU HAD SOME WORK ON THAT; COULD YOU ELABORATE A BIT?

DR. KOZAK: Absolutely. I'm lucky to work with Dr. Gary Kobinger from Université de Laval, who I met at the National Lab, working on Ebola. Early on in the in the pandemic, we were working to develop some antibodies with help from Dr. Mario Ostrowski, who was able to get some cells from a recovered patient.

So, these antibodies that they developed in Laval were shown to neutralize the virus in vitro, which basically means you mix the virus with antibody and show that it can't infect cells. Our plan moving forward is to test them in mice. We will infect the mice with SARS-CoV-2, dose them with antibodies or placebo, and see if there is a difference in infection and severity between these two groups.

\begin{abstract}
MARTIN: INTERESTING! WHAT PROTEIN ARE YOU TARGETING WITH THESE MONOCLONAL ANTIBODIES?

DR. KOZAK: It is the spike. That's usually the best one to go with because that's the protein that the virus uses to attach onto the cell.
\end{abstract}

MARTIN: YOU MENTIONED YOUR INTEREST IN VACCINOLOGY AND THAT YOUR LAB WAS INVOLVED IN DEVELOPING A DNA VACCINE. IS THAT CORRECT?

DR. KOZAK: That's right. Again, this project is a collaboration with Gary, who has been interested in DNA vaccines for a while. My postdoc, George, and I started working on it back in January, just designing the antigen and cloning it into the system. As part of the whole vaccine development process, we have been trying different versions of the antigen and the vector which we thought might enhance immune expression, and testing in different animals. The thing that we like about it is that it induces both B cells and T cells, which is especially good for viruses since you need T cells to be activated as well.
It's very safe because it's just DNA rather than a live virus, a part of the virus, and you can make lots of doses easily because it's all synthetic. Now we just have to do safety screening and seeing how many doses would be required in humans to achieve the same protective effect. I've applied to the CIHR and hopefully they're going to read your article and say, "We've got to give this guy money!". So, fingers crossed!

MARTIN: HOPEFULLY! MECHANISTICALLY, HOW DOES THE DNA VACCINE WORK AND COMPARED TO THE MRNA VACCINES ALREADY ON THE MARKET?

DR. KOZAK: Basically, if you remember from first year biology, the central dogma says we go: DNA, RNA, proteins. You can deliver an antigen at any of those steps and provide it to the immune system. With mRNA vaccines, it's just the RNA that gets converted into proteins which are detected by the immune system and generate an immune response. The DNA vaccine is just a step earlier. Mechanistically, there is a very strong promoter and enhancer on it so that it produces lots of antigen in the cells that then produce lots of mRNA, which gets converted into protein and activates the immune response.

MARTIN: I KNOW MRNA IS VERY FRAGILE, AND ACCORDINGLY, THE PFIZER AND MODERNA VACCINES HAVE TO BE KEPT AT VERY LOW TEMPERATURES. IS THE DNA VACCINE MORE STABLE?

DR. KOZAK: Yes, probably - that's one of the things that we really like about it, although you likely still need to refrigerate it. However, it's a lot easier to since it is less sensitive than mRNA - we probably won't require the minus 80 freezer capacity. From a global health perspective, this is important to be able to deliver vaccines to remote areas. Remember, no one in the world is truly safe until everybody is truly safe.

MARTIN: YOU TOUCHED ON THIS EARLIER, BUT HOW IMPORTANT IS IT THAT WE CONTINUE VACCINE DEVELOPMENT, DESPITE THE FACT THAT THERE ARE ALREADY VACCINES OUT THERE?

DR. KOZAK: To me, it's something where we absolutely shouldn't get overconfident and take our foot off the gas, because there's a lot of people in the world, and a lot of different vaccine situations. Until we achieve global herd immunity, the virus will keep mutating, and it will have every motivation to try and get ahead of us.

MARTIN: VERY GOOD POINTS. WHAT ARE THE SCIENTIFIC FACTS AND LESSONS THAT WE'VE LEARNED FROM THIS PANDEMIC, AND HOW WILL WE USE THEM FOR THE NEXT ONE?

DR. KOZAK: That's a really big question. From what I've seen, and from what I do on the testing and lab side 
of things, it is very important that we have the ability to scale up capacity. We have seen how important it is to get testing to everybody - that is how you control a pandemic before there are good vaccines and therapies. Second, we obviously need to be prepared, to be doing active surveillance. I hope now that people realize that these types of zoonotic pathogens are not things we can ignore, and that infectious diseases and pandemics will be regarded almost as national security threats.

MARTIN: ONE OF THE THEMES YOU'VE TOUCHED ON, AND THAT WAS PROMINENT THROUGHOUT THE CONFERENCE, IS THE IMPORTANCE OF SCIENTIFIC COLLABORATION. HOW HAS THE PANDEMIC ENHANCED OR CHANGED THE WAY WE'RE DOING SCIENCE?

DR. KOZAK: There were a couple of things. Firstly, we've certainly had a lot more open source science, like preprints. But you also saw people share idea when they figured something out. There's also been lots of - some formal and some informal - networks, where people have shared information shared. For example, when we did the virus isolation back in March, I wrote to some colleagues in China, and to a virologist in Australia who had also been isolating the virus - Dr. Mackay, (check out his blog: Virology Down Under) so that we would avoid same speed bumps and mistakes. So, I think it's been great because you see a lot of people wanting to work together.

MARTIN: EXACTLY. WHAT ADVICE WOULD YOU GIVE TO YOUNG ASPIRING SCIENTISTS THAT ARE LOOKING TO CARRY THIS TORCH, AND YOU KNOW, RESEARCH THE NEXT PANDEMIC OR OTHER PRESSING ISSUES?

DR. KOZAK: I think it's great and I would absolutely encourage people to go into research. Follow what you what you're interested in because there will definitely be times when it's hard, and you know, experiments are not working, people don't want to publish your papers, and if you are not passionate about it won't work out.

But to just give a one sentence piece of advice, one that I learned from my previous supervisor, Gary Kobinger, who always had a saying: "it's always better to collaborate than compete". Work together and you will publish more, do more, learn more, and enjoy science a lot more than if you try to do it by yourself!

\section{COMPETING INTERESTS}

No competing interests declared.

Received: February 20, 2021

Accepted: July 2, 2021

Published online: July 31, 2021

The previous interviews have been edited for clarity. Martin Profant is a student at the University of Toronto and a Staff Writer for the JULS. Please address correspondence to: martin.profant@mail.utoronto.ca 